\title{
BMJ Global Health The merit privilege: examining dubious claims of merit in public health and public policy
}

\author{
Prashanth Nuggehalli Srinivas
}

To cite: Nuggehalli Srinivas $P$. The merit privilege: examining dubious claims of merit in public health and public policy. BMJ Global Health 2021;6:e006601. doi:10.1136/ bmjgh-2021-006601

Received 12 June 2021 Accepted 29 June 2021

Check for updates

(C) Author(s) (or their employer(s)) 2021. Re-use permitted under CC BY-NC. No commercial re-use. See rights and permissions. Published by BMJ.

Health equity cluster, Institute of Public Health Bangalore, Bangalore, Karnataka, India

Correspondence to Dr Prashanth Nuggehalli Srinivas;

prashanthns@iphindia.org
'Personally, I rather look forward to a computer programme winning the world chess championship. Humanity needs a lesson in humility', said Richard Dawkins, author and biologist, whose witty ripostes delivered with a signature smirk, typically directed at the religious, captivated my rational mind. These were the late 1990s. We were in our medical college hostel's chit-chat corner where some of us with wide interests in science gathered every evening. Under the medical college men's hostel banyan tree, our discussions typically focused on the latest sample of writing that dismantled foolish arguments of naive (religious) believers. Dawkins's books and writing provided plenty of such material. Here was an intellectual behemoth often pitted against hobnailed ignorami bringing cheer to us young professionals, looking up to him, as if one from our own team had scored a winning goal.

Today, as a doctor and a public health researcher, I look back at this chit-chat among the then doctors in the making. The higher knowledge that accrued to people like me, doctors, scientists and academia, gave us access to pedestals from which we could now be the new saints: rational and legitimate preachers unlike the ones we aim to displace, the ones we would like to call out for their boorish, irrational and unscientific foundations. In fact, I realised it was our meritorious ascent that is foundational to our pedestal. But how strong and deserved are our own foundations, I wondered. Should we not, before calling others out, examine our own backyards? So emerges the tale of two merits: science itself as an act of merit and the scientist professional's aspirational society where people rise to the top based on well-deserved fruits of their labour through merit and nothing else. Could a well-designed meritocracy then help us overcome centuries of social baggage in the form of caste, class, gender and such that the new India would like to leave behind?

\section{SCIENCE'S MERIT CLAIMS}

The progress of university-based modern science has its foundations in the dismantling of centuries-held superstitious beliefs. Perhaps given its fashioning in the renaissance cauldron in tumultuous 14th-17thcentury Europe, science has taken on itself the noble task of delivering us from falsehoods. For postcolonial societies like ours, pursuit of university-based education thus becomes akin to shedding tradition, losing the stuff that came from the irrational and the unfounded, to embrace the proven and tested. Science becomes a tool for adjudicating knowledge itself, at least the science that is often accessed by the meritorious among us, the 'truly deserving': the doctors, the engineers and the scientists, the ones who would like to bring forth the fruits of such meritorious sciences to uplift society. This is often cast as an apparently noble endeavour of generously sharing the fruits of our merit with the wider society.

Modern science and technology have certainly lived up to their promise; there have been enormous strides in terms of understanding the world around us as well as modifying and bending it to our needs. Besides the ability to extract natural resources and create megastructures like dams, satellites and the information communication architecture, modern science is also a sociopolitical animal, demanding a seat at the public policy table and promising societal awakening through evidence-based solutions to the wicked problems of our time. Coming from public policy and planning literature, characterisation of the biggest challenges facing society today as wicked stems from the social complexity that underlies these challenges. Urban planning, 
health inequalities, climate change and community engagement are few examples of such problems that require humbler and more participatory approaches as opposed to authoritative and overcentralised approaches that often are our immediate response. ${ }^{1}$ Advanced scientific research methods like randomised control trials (RCTs) that had their origins in proving whether a given substance can be effective as a treatment (even cure) of human disease today make a play at addressing poverty and improving public health. The 2019 Nobel Prize for Economics to Banerjee, Duflo and Kremer who have been champions of using RCTs to solve development issues marks the culmination of the arrival of economics in public policy. Economics is a social science where theories and concepts are advanced as explanations rather than as universal truths (cf. gravity in the natural sciences). The jump from the use of RCTs in clinical medicine to economics and public policy has happened with limited adaptations. Today, economists design social experiments that help establish the effectiveness of one development approach over another after testing them in 'controlled conditions'. While the idea of creating controlled conditions for experimentation within societies can itself be debated along ethical lines, there is also the lack of a reasonable scholarship in economics from the Global South (eg, South Asia and Africa) where such approaches are increasingly being tried out. ${ }^{2}$

What stands out though is the higher intellectual pursuit of a few, within academia and knowledge-based communities, which is aimed at delivering equity and justice for all. Even outside economics, in general, science and scientific approaches are today pursuits of intelligent few who have demonstrated high academic merit to attain positions of respect in universities and academia. In addition, they also aim to provide us tools to shape and even 'fix' societies. Those that have seen the light through PhDs and research chairs in these evidence-based public policy communities spanning public health, economics and development scholarship possess a higher truth that is inaccessible to the unlettered, unfamiliar to equally lettered but in another discipline (a PhD in sociology, eg, may be excused from knowing the intricacies of the immunology of the COVID-19 vaccine), or un-understandable to many others who may be insufficiently literate. For instance, current definitions of literacy do not automatically translate into abilities to engage in scientific debates. The nature of these debates and their paywalled and English-language platforms are such that literacy may be necessary but not sufficient to engage in scientific debates. This is in no small part due to the reproduction of social inequities within educational institutions and scientific establishment. See, for instance, the stereotype in portrayal of 'rock stars in science'.

In one quick sweep, the intended beneficiaries of these sciences are robbed of any stake in their own deliverance. Whom can we blame but the individual, if they were not smart enough to get university education or if they were unable to get to a sufficiently reputed university.
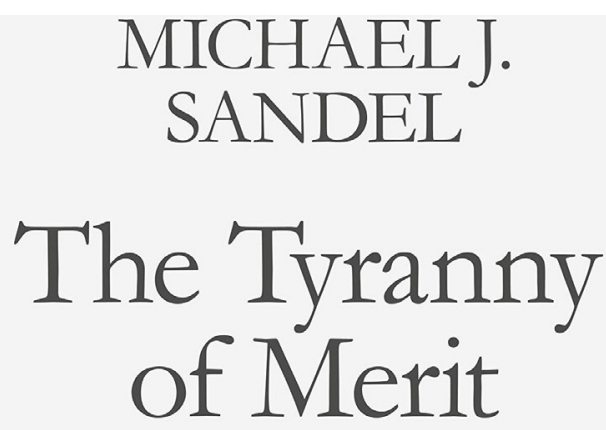

What's Become of
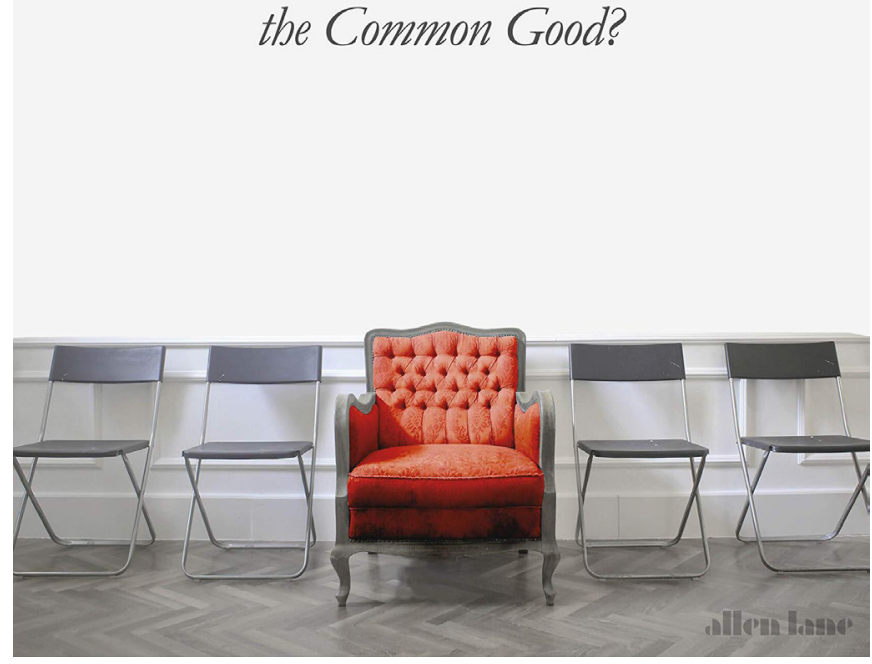

Figure 1 The Tyranny of Merit by Michael Sandel (September 2020).

\section{ORDERING SOCIETY AS IF MERIT MATTERS}

In The Tyranny of Merit: What's Become of the Common Good?', Michael Sandel presents a withering critique of merit and its apparently rightful claim for a higher seat. Sandel, a Harvard academic and a US political philosopher, brings into question the merit of merititself (figure 1). His dialecticstyle lectures on justice delivered in real-world Harvard classrooms ${ }^{5}$ had already questioned the thick privilege at the core of apparently merit-based admissions processes in leading US universities including his own. Students in his justice classroom debate the so-called legacy admissions process, which places children of alumni higher up on the merit queue. Similar hereditary privileges also prop up children of philanthropists who secure such 'merit' for their children. By astutely contrasting models of merit bought by philanthropic donations, with backdoor entry into colleges secured through counterfeit certificates, ${ }^{6}$ he tears down the distinction between these two. His book poses the uncomfortable question of particular discomfort to academics like me: is merit too actually a backdoor rather than the much-feted front porch that we would like it to be held up as? Sandel eloquently outlines how even if our social and political institutions were to deliver us a true meritocracy it would not '...be satisfying, either morally or politically'. 
Sandel challenges the popular imagination of merit, often characterised as being fantastic in theory but often failing in practice. This accrues from merit's innate moral appeal to a superiority that we think is universal, as if those judged less meritorious in an apparently objectively applied test of merit will not only accept but also perhaps celebrate their loss and someone else's win. This provides a simplistic answer to how to achieve equity and justice: just building mechanisms that reward the 'truly meritorious' while at the same time ensuring that everyone irrespective of their birth or identity has the opportunity to benefit from such true merit. According to this naive conceptualisation of a meritocracy, the existence of an equal opportunity would automatically remove any subsequent discomfort from the 'loser'. Having lost, she cannot feel cheated; after all, there was a fair process, so what can she whine about? Sandel dismantles this theoretical appeal to merit by demonstrating that the very notion of such universal opportunities is so impractical or idealistic. They have remained as values to aspire for, and have never been realised in practice, universally.

The idealism aside, even if a meritocracy was indeed realised, it would be paradoxically undesirable. Constructed on the foundation of 'to each her own', it would place every single benefit that accrues to a person in their life to them alone, as if there is no stake for anyone/anything else. This assertion, an underlying principle of meritocratic arguments, is flawed, not only because it does not hold up to moral scrutiny but because it will not even hold up to free market principles. Many who root for privileging merit in structuring society would uphold the free market's ability to choose champions without batting an eyelid.

Sandel provides parallels to this in arguments of morality that have shaped thinking in multiple Christian traditions. An important historical and spiritual point of departure for divergent streams of thought in Christianity have centred on whether all human beings deserve (biblical) salvation or is it only for those who earn the grace of God, foregrounding the idea of desert (or deservingness based on one's acts or attributes). Indeed, entire sects of religions-not only Christianity-have diverged in their philosophical positions on who deserves such fruits of labour (or even just prayer)! A bizarrely familiar expounding of such reasoning is the idea of one nation or one kind of people being exceptional or better merely because they deserve to be identified as such due to a denominational, geographical or ethnic national identity. Sandel provides the example of how US exceptionalism has been shaped by such arguments. Indeed, supremacist nationalism anywhere reminds us to ask ourselves as to what moral arguments underlie one nation or one people's claim to deserve better (or more), recalling John Rawls' rejection of moral desert (or deservingness) through attributes accruing from one's birth into a certain family, status or nation.

Of course, this is no new argument, certainly not for western philosophical traditions with the arguments between those who locate every single achievement within individuals' grit, hard work and determination and others who situate achievement within society and its institutions (including family, peers, neighbourhood and of course public institutions like schools and colleges) with contributions across generations. While this is a centuries-long argument, two particular facets of recent discourse in India that are closely interlinked can be located within this debate. One relates to India's flourishing socioeconomic growth and the other its historical social institutional design.

\section{MERIT'S OWN BIASES}

First, on India's socioeconomic engine, only a ragtag locomotive in the 1960s and the 1970s, shackled by centuries of extractive colonial practices before independence in 1947 , it acquired a sleek bullet train feel by the 2010s. Macroeconomic reforms and market liberalism resulted in enormous benefits to many, if not all; many Indians rapidly experienced newer set of amenities and institutional arrangements, some of these in many rural areas, although heavily patterned depending on which state, district, taluka and neighbourhood one lives in.

In this new India, gone is the lazy State of the 1970s and 1980s, and nothing can hold back the individual 'go-getter' but their own lack of initiative. Those feeling left behind not only are to blame for their own deprivation but also might in fact be complicit in holding all of us behind by pulling down our average growth statistics. Until recently, entire geographies were characterised as being BIMARU and thus somehow 'holding us back'. Loosely translated into sickly in Hindi, BIMARU as an acronym featured even in a popular Indian textbook of community medicine read by many medical students of the day. It stood for central and north Indian states of Bihar, Madhya Pradesh, Rajasthan and Uttar Pradesh. These were often problem states that were pulling down all the national averages bringing disrepute to the hard work and prosperity that other states were achieving.

Although the word itself has thankfully disappeared from development literature in the last decade, castebased and class-based characterisation of entire states, landscapes or geographies continues to thrive. Similarly, if these many years of nutrition supplements and freebies and reservation in jobs and educational institutions cannot create enough drive, perhaps 'these people' are just the antithesis of merit? Despite strong constitutional basis for and widespread evidence of the need for more affirmative action, ${ }^{7}$ it tends to be often characterised as an act of benevolence of some of us on others rather than an act of restoring rights and achieving inclusive growth. What appears to be purely economic arguments about free markets quickly reveals a dark moral underbelly in positing how human society ought to be ordered. And this brings up the more devious second.

Our society is already organised by caste. Over and above status accruing from income, wealth and other 
social markers, caste already delegates desert (or deservingness) according to birth, a devious and paradoxical scenario where rather intangible intergenerational privilege and advantage that Sandel describes as a corrupting influence on merit-based US ivy league school educational process have in fact been ossified into social structures that regulate desert (or deservingness) in our society. A timely reading in this regard is Isabel Wilkerson's Caste $^{8}$ that according to the Dalit writer Yashica Dutt '...brilliantly frames racial hierarchies in the United States but largely ignores the horrors of India's caste structure'. ${ }^{9}$

\section{LIBERAL PRIVILEGE BLINDNESS}

One of the hallmarks of the kind of society that portrays itself as uplifting the truly deserving is one in which anyone shall 'reap as per their effort' irrespective of who they are. Free markets excel in reinforcing this illusion of reward based on effort. As the famous saying goes, teaching someone to fish is better than giving free fish to someone. But of course as another saying goes, you can only take the horse to the water, but you can't make him drink if he does not want to benefit from the sweet waters of success. Automatically, those who are not drinking the water despite its availability are to blame themselves.

Generations of Indians born into families that believe they have shed their markers of caste or class privilege through giving up their last names, apparent caste markers in clothing/adornments or apparently modern and liberal talk of equality in their homes may not realise why their parents and ancestors, for example, were already ahead in the race through generations of accumulated privilege. Brought up in such homes, shielded from the dehumanising prejudice that caste discrimination unleashes on others far away from them, attending carefully selected private schools where they don't see this or playing in clubs and playgrounds where these markers are unheard of among their peers, they enter professions and academia blithely unaware of how privilege and status have been at work in shaping an unfair society. They ironically feel 'cheated' of their entitlement when they see doles and reservations to others.

In fact, by the time we were in medical college, there were plenty of 'eye-opener' opportunities to raise our consciousness: be it the hierarchical and gendered doctor establishment that treated nurses and paramedical trainees and staff as 'second class' or the class-based differential treatment that is often routine practice in government hospitals or even that dark horse reference to those classmates of ours who secured entrance to medical colleges 'only because of reservation'. An often heard remark among 'merit' students in India, rarely also appearing in social and print media, is the complaint that 'undeserving' candidates are stealing away educational and job opportunities from the truly deserving merit candidates.

The death by suicide of Payal Tadvi ${ }^{10}$ and Rohith Vemula's words 'My birth is my fatal accident...' from the note he left ${ }^{11}$ are two recent examples of the humiliation to Dalit and Adivasi students, which comes from a place of wanting to reclaim merit in educational institutions. Many opportunities that could raise consciousness about adverse social orders just passed by, at least for me, (then) shielded by my liberal privilege. Some might graduate a small step forward but only look at these affirmative action policies as acts of benevolence and compassion, which they must tolerate instead of what they are: inadequate efforts at an apparent equalisation of opportunity. Perverse social ordering by caste, class and gender creates an unequal and unfair playground. It is in fact not that we, the privileged, did not work hard (although many of us probably did not!). This is not about us at all. It is about whether we the privileged shall endorse a society where despite generations of hard labour some of us do not advance at all or even worsen, while others ascend rapidly in one generation. Is that rapidity entirely because the 'winner' is smarter and more intelligent? Are we going to gloat over a success that is inherently unfairly gained?

What does a meritocracy mean to those who have to run the same race as all of us but carrying so to speak an intergenerational baggage, often literally carrying our baggage for us while expecting to run this race with us. In these conditions, even if a true meritocracy was to operate, it would only require a large section of us to feel truly deserving of a second, third or a last class or place. Sandel's examples of how only few of the poor or black people in the USA truly make it to the top apply to many other countries as well and certainly to India. In Sandel's words, 'If meritocracy is an aspiration, those who fall short can always blame the system, but if meritocracy is a fact, those who fall short are invited to blame themselves'. A true meritocracy paradoxically invites a sense of humiliation on those who do not succeed, more so if we do achieve that elusive fair process of structuring society as per merit, because fairness after all is not about the one Obama or another Kamala. Their charisma and exemplary journeys pale among several others who ran as much if not faster, but did not move.

\section{CLAIMING MERIT'S REWARDS TO ONESELF}

A case in point is the anger and frustration expressed by many doctors and recent medical graduates at the rules for compulsory rural service imposed by some state governments. ${ }^{12}$ In their view, this was unfair. One argument suggests that they were being prevented from enjoying the fruits of their own labour (many students asserted their merit in obtaining the seats through a competitive process). In their view, a year of service in a rural area was being imposed on them by the government due to its own failing in resourcing these areas with well-paid doctors. They were feeling robbed of 1 year of their otherwise lucrative life in favour of improving public health. 
There are indeed cogent arguments for reforms that could make rural service more attractive, thus drawing doctors to opt for these out of their own volition. However, young doctors' claim that their achievement in obtaining medical degrees is theirs alone, and the state was wresting a small portion of their own (1 year in a typically 40-year run as a doctor) that is fuelling a sense of being 'cheated'. This is not new; in 2019, for instance, the campaign to get 'the doctor you deserve' (as opposed to doctors that come through reservation) briefly trended signalling that doctors who obtain seats through affirmative action may be suboptimal. ${ }^{13}$ In this instance too, upper caste doctors' antireservation stance was indeed ironic, as pointed by an anonymous doctor, as glaring 'backdoors' through management quotas and various other obvious 'antimerit' entries that are rarely protested against. ${ }^{13}$ Here too, seats obtained through constitutionally protected affirmative action were perceived as an act of diminishing one's own well-deserved 'merit' seat.

Both these instances recall Sandel's assertions in his book about how even choosing some professions over others is often shaped by what societies value, thus, in fact, shaping what appears to be free choice. In that sense, choosing to become a doctor and the status accruing to a doctor is as much a manifestation of how the wider society views doctors, as much as it is an individual enterprise. Calling out such 'meritocratic hubris' that neglects luck, good fortune and unfair distributions of privilege in shaping a given individual achievement leads to a '...smug conviction of those who land on top that they deserve their fate and that those on the bottom deserve theirs, too', an attitude that Sandel calls the 'moral companion of technocratic politics'.

\section{FALL OF THE MERIT IDOLS}

Thinking back on my college science heroes, I now realise that my own liberal shields prevented me from seeing the overwhelming white maleness of my merit idols. When the popular US astrophysicist Neil deGrasse Tyson, known for his public engagement on science, asks Richard Dawkins ${ }^{14}$ about the sharpness of his critique of those who were religious, he reminds Dawkins '...you are a professor of the public understanding of science, not professor of delivering truths to the public.... Being an educator is not just getting the truth right, but there's got to be an act of persuasion there as well. Persuasion isn't always here are the facts-you're an idiot, or you are not. But, here are the facts, and here is a sensitivity to your state of mind, and it's the facts plus the sensitivity, which together create impact.... I worry that your methods and how articulately barbed you can be ends up simply being ineffective when you have much more power and influence than what is currently reflected in your output'. Although 'gratefully accepting the rebuke', Dawkins responds by quoting an editor of the leading science magazine, New Scientist, who when asked about their philosophy supposedly quips 'Our philosophy at
New Scientist is this: Science is interesting. And if you don't agree, you can fuck off ${ }^{14}$

My medical college days champion of science and rationality had failed his own humility test. Time and time again, many such behemoths have crumbled in public imagination, excelling in science but not necessarily open to listening to how their own position and journey might be reproducing adverse societal prejudice of one sort or another. Writing in the Atlantic, Marina Coren points out how Lawrence Krauss, another scientist on my science celebrity list, often appearing in Dawkins' company, feels that the scientific enterprise quite automatically overcomes gender biases merely by its design: 'Science itself overcomes misogyny and prejudice and bias. ${ }^{15}$ It's built-in', Krauss uncritically said last year during a promotional event for one of his books. Unsurprisingly, the scientific establishment has had the need for the same rude awakenings of sexual harassment and discrimination that all other professional arenas faced prompting Leila McNeill's takedown of another celebrated scientist, Richard Feynman, in an article titled Surely You're a Creep, Mr. Feynman. ${ }^{16}$ Many such white male idols of mine either chipped or crumbled, and turns out such crumbles are not only reserved for white men, but cut across scientific and social institutions reminding us that none are immune to locating problems far away in society while refusing to look within.

\section{PUBLIC POLICY: A FEW MERITORIOUS MEN APPROACH?}

An illusion of true merit can in fact easily shape public policy and possibly does so in the USA where each president appoints people with the best qualifications for the job in their cabinet or in their public policy-shaping bodies. In a meritocracy, the smart people are the ones who have all the ideas for delivering the rest. In such a system, we would look for answers to shape society within our most elite scientific research institutions and our academic expert committees. Efforts at bringing meritocracy into public policy have only recently acquired some traction in India. Degrees in public health or public policy that were until recently available only in European and US institutions have come up in Indian universities as well, although so far making relatively limited inroads into public policy. On the other hand, Indian public policy has been demonstrably accessible to powerful interests in industry, for example, which through formal and informal routes acquires a seat at the policy table. However, Sandel reminds us that perhaps moving from industry or private interests to an expert-led meritocracy may only be replacing one problem with another. Such a shift may only be layering a technocracy over a plutocracy instead of a deliberative democracy. In the latter system, a critical engagement with dissent, diversity and creating vibrant deliberative spaces at the lowest level would be preferred over having the best person for the job. 


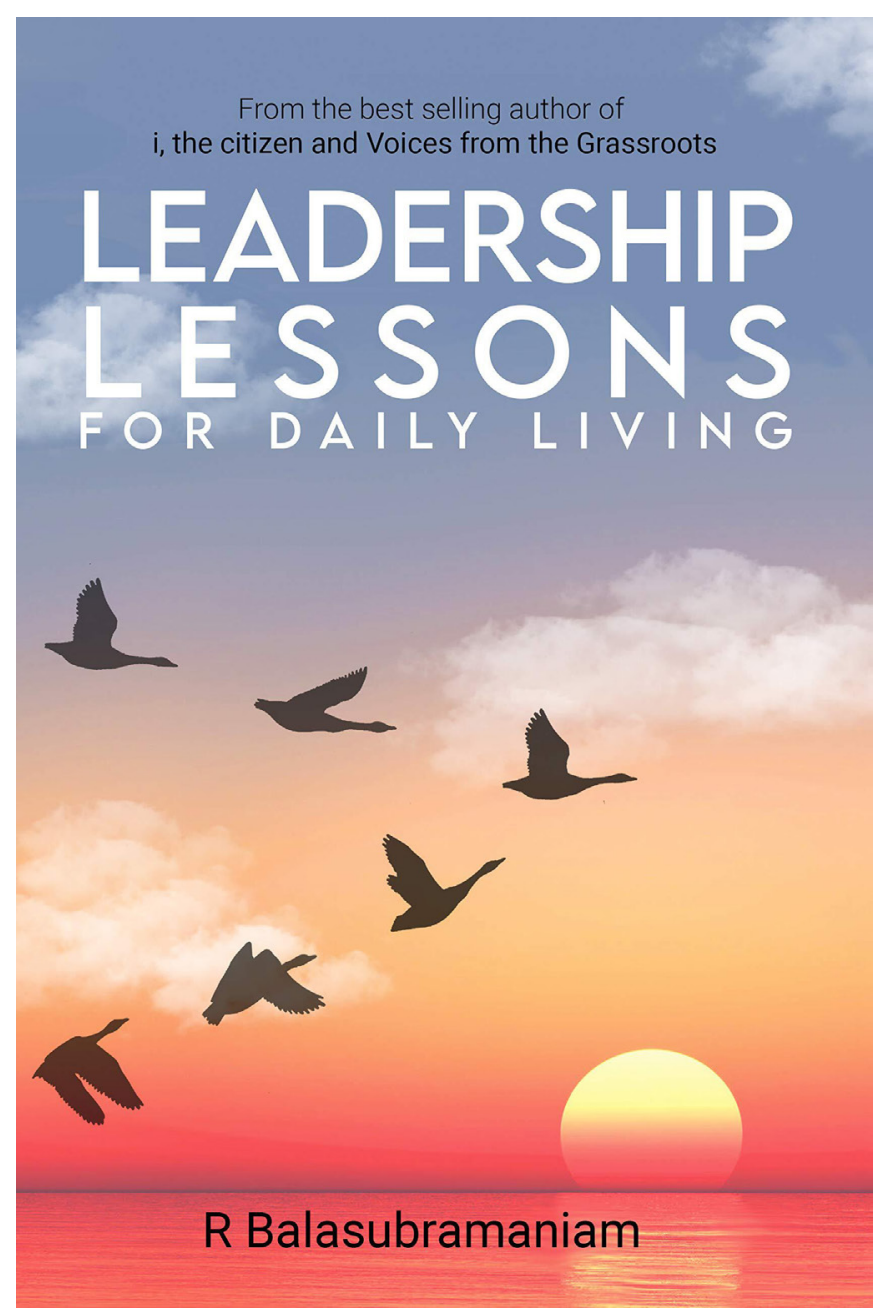

Figure 2 Leadership Lessons for Daily Living by R

Balasubramaniam (August 2020).

\section{TOWARDS A HUMBLER ENGAGEMENT WITH SCIENCE AND SOCIETY}

The problem with science and academic effort at shaping public policy based on scientific evidence is because of the exclusionary history of our enterprise; this makes it disempowering at the least and exclusionary at its worst. Various narratives, peoples, ideas and voices have not (yet) featured among Indian science, scientists and academia. Sandel's takedown of meritocracy beckons the need for a discussion on the kind of leadership needed within universities and academia, especially in those which aim to engage with public policy. This includes medical colleges, schools of public health and public policy and certainly the multitude of social science disciplines including economics, arts, social work and other development disciplines.

In an era in which the decolonisation debate ${ }^{17}$ seeks idols from our own society as opposed to far-away white male idols, another book published in late 2020 on transformative leadership by $\mathrm{R}$ Balasubramaniam comes to mind $^{18}$ (figure 2). Although not pursuing depth of discourse, nor layered academic scholarship that abound in western development literature, the book draws on the author and his colleagues' rich experience in pursuing development while working among rural and Adivasi communities in southern Karnataka and elsewhere in his several decades of journey as a grassroots development scholar. Balasubramaniam's work in setting up the Swami Vivekananda Youth Movement in southern Karnataka stands among few such efforts where doctors and other professionals seek to learn together in communities rather than arrive knowing what needs to be done.

Growing up in an urban middle-class family, he describes the need for crucible events, which test one's belief systems and core values and '...can set the stage for adaptation and reflecting on them can help a person stay humble and grounded'. The book recounts everyday stories of apparently uncharismatic people that he comes across, and the lessons he infers from these stories foreground the need for an internal journey of reflection and accepting our own vulnerabilities before offering our compassion, benevolence and-God forbid-our hubris for uplifting others. The authors' lessons emerge from multiple grounded experiences, many of which were failures of his imagination, which he gladly accepts and learns from, all the while being open to learning more and bowing more.

The overwhelming leadership lesson emerging from the book is that the more one's apparent power and influence, the more the need to bow and learn. Most of the book features people who may not be on Twitter or Facebook nor have any internet footprint, a refreshing reminder that there is an India outside of what we read and react to online and in fact where mountains of work still need to be done despite all the celebrations we can have about macroeconomic achievements.

While one chapter features Muthaiah, a leader of the Solega people in southern Karnataka, and his individual struggles in leadership and his community's quest at securing rights over ancestral land that has become the hallmark struggle for any indigenous community globally, another features Kamakshi, a woman whose father's stern decision to secure education for all three of his daughters was foundational to her success in becoming an entrepreneur in her village. The Solega people live in and around forested regions in southern Karnataka at the tri-junction of three states. They identify as one of the Adivasi (first people/indigenous people) of the area and are one of the several Scheduled Tribes as per the Indian constitution's provisions for affirmative action. Many of the Solega, for instance, celebrate the work of another social activist, Hanumappa Sudarshan, whose work in organising them speaks much more in the on-ground action achieved than in its ability to garner citations in high-quality journals. ${ }^{19}$

The stories in the book illustrate the struggles many people face in being able to reach a level playing field that was already level from the get-go for people like me (although few chapters focusing on more charismatic and powerful leaders did not resonate as strongly to me as others from the grassroots). Yes, people like Muthaiah 
and Kamakshi demonstrate extraordinary leadership in their daily life as they navigate adverse social structures that may not be intentionally willed into place by many of us yet shape the destinies of who shall benefit from merit and more importantly who shall not.

The book's musings on leadership contrast with our expectations from organised knowledge systems such as the scientific enterprise. The scientific enterprise after all is emerging from an exclusive meritocratic project that aims to identify the best of the best. Sandel does not necessarily provide a neat alternative to the technocracy. But by foregrounding human dignity irrespective of one's birth, social position or apparent success or failure, his book carries an important lesson for both academia and academically grounded civil society. Both of these give unto themselves the mandate of advancing societal goals for all-including those who are neither academically qualified nor themselves involved in activism. These are the others for whom academia and mainstream civil society seek to work. After all, the problem of hubris is ours in academia and civil society-not theirs. And it is time to look within us before we find answers for them.

Being born into multiple axes of privilege endowed me with an ability to fully experience my liberties. And the two decades after medical college have put me on a path of raising my own consciousness about the social sanctions to people's liberties that can remain despite constitutional and political intentions to the contrary. If the aspirations of academic research to contribute to equity and justice are to be trusted, then its idols, methods and norms honed through multiple isms (colonialism, sexism and casteism, to name a few) need to be deliberated and addressed. This can only happen through an honest acknowledgement of our own problems in academia and research before we proceed to 'liberate' the masses.

What we don't problematise, we will not solve.

Twitter Prashanth Nuggehalli Srinivas @prashanthns

Acknowledgements I would like to thank several individuals, some of which are friends, relatives, colleagues and collaborators from multiple communities and social positions whose love, indifference, frustrations and even outrage have helped shape this reflection.

Contributors NSP was involved in conceptualising, drafting, reviewing and finalising of the article.

Funding The authors have not declared a specific grant for this research from any funding agency in the public, commercial or not-for-profit sectors.

Competing interests I have volunteered with Swami Vivekanada Youth Movement as a medical student in 2002-2003. I am a member in voluntary capacity at the Vivekananda Girijana Kalyana Kendra (VGKK), the NGO founded by Dr H Sudarshan, who is mentioned in this article. In my current salaried role at IPH, Bangalore, I have ongoing collaborative research engagements with VGKK as well as with the community-based organisation of the Solega people.

Patient consent for publication Not required.

Provenance and peer review Not commissioned; externally peer reviewed.
Data availability statement There are no data in this work.

Open access This is an open access article distributed in accordance with the Creative Commons Attribution Non Commercial (CC BY-NC 4.0) license, which permits others to distribute, remix, adapt, build upon this work non-commercially, and license their derivative works on different terms, provided the original work is properly cited, appropriate credit is given, any changes made indicated, and the use is non-commercial. See: http://creativecommons.org/licenses/by-nc/4.0/.

ORCID iD

Prashanth Nuggehalli Srinivas http://orcid.org/0000-0003-0968-0826

\section{REFERENCES}

1 Almeida AC, Paul C. Wicked problems and how to solve them. The conversation, 2018. Available: https://theconversation.com/wickedproblems-and-how-to-solve them-100047 [Accessed 10 Jun 2021].

2 Arvind S, Devesh K. The absent voices of development economics. project Syndicate, 2021. Available: https://www.project-syndicate. org/commentary/why-does-the-global-north dominatedevelopment-economics-by-arvind-subramanian-and-deveshkapur-2021-03 [Accessed 10 Jun 2021].

3 Tanner KD. Learning to see inequity in science. CBE Life Sci Educ 2009;8:265-70.

4 Sandel M. The tyranny of merit. Penguin Books, 2020

5 Harvard University. Justice with Michael Sandel - YouTube, 2014. Available: https://www.youtube.com/watch?v=kBdfcR-8hEY\&list= PL30C13C91CFFEFEA6 [Accessed 10 Jun 2021].

6 Durkin E. Us College admissions scandal: how did the scheme work and who was charged? the guardian, 2019. Available: https://www. theguardian.com/us news/2019/mar/12/college-admissions-fraudscandal-felicity-huffman-lori loughlin [Accessed 10 Jun 2021].

7 Bhojani U, Madegowda C, Prashanth NS, et al. Affirmative action, minorities, and public services in India: charting a future research and practice agenda. Indian J Med Ethics 2019;4:265-73.

8 Wilkerson I. Caste: the origins of our discontents. United States of America: Random House, 2020.

9 Dutt Y. An Indian Dalit Reading of Isabel Wilkerson's Bestseller "Caste." Foreign Policy, 2020. Available: https://foreignpolicy. com/2020/09/17/caste-book-india-dalit-outcast wilkerson-review/ [Accessed 10 Jun 2021].

10 Satheesh S. Payal Tadvi suicide case: the death of a doctor. mint 2019. Available: https://www.livemint.com/mint-lounge/features/ payal-tadvi-suicide-case-the-death of-a-doctor-1559891147950 html [Accessed 10 Jun 2021].

11 The Wire Staff. My Birth is My Fatal Accident: Rohith Vemula's Searing Letter is an Indictment of Social Prejudices. The Wire, 2019. Available: https://thewire.in/caste/rohith-vemula letter-a-powerfulindictment-of-social-prejudices [Accessed 10 Jun 2021].

12 TNM Staff. Karnataka govt to crack the whip on doctors who SKIP compulsory rural service. The news minute. Available: https://www. thenewsminute.com/article/karnataka-govt crack-whip-doctorswho-skip-compulsory-rural-service-62372 [Accessed 10 Jun 2021].

13 Anonymous. A Young Doctor's Appeal: Let's Understand Privilege Before We Talk Merit. The Wire, 2019. Available: https://thewire.in/ caste/caste-medicine-student-privilege-merit [Accessed 10 Jun 2021].

14 agillesp123. Dawkins vs. Tyson - YouTube, 2006. Available: https:// www.youtube.com/watch?v=-_2xGlwQfik [Accessed 10 Jun 2021].

15 Coren M. The fall of celebrity scientist Lawrence Krauss. The Atlantic, 2018. Available: https://www.theatlantic.com/science/ archive/2018/10/lawrence-krauss-sexual misconduct-me-tooarizona-state/573844/ [Accessed 10 Jun 2021].

16 McNeill L. Surely You're a Creep, Mr. Feynman. The Baffler, 2019. Available: https://thebaffler.com/outbursts/surely-youre-a-creep-mrfeynman-mcneill [Accessed 10 Jun 2021].

17 Roy RD. Decolonise science - time to end another imperial era. The wire science, 2018. Available: https://science.thewire.in/thesciences/decolonise-science-time-to-end-another imperial-era/ [Accessed 10 Jun 2021].

18 Balasubramaniam R. Leadership lessons for daily living. 1st ed. GRAAM \& ILSS, 2020.

19 Coombes R. Hanumappa Sudarshan: the quiet reformer. BMJ 2009;338:b1794. 